\title{
Disclosure Quality and Firm's Characteristics: Evidence from Iran
}

\author{
Nasrollah Takhtaei \\ Accounting Department, Dezfoul Branch, Islamic Azad University, Dezfoul, Iran \\ E-mail: nasrollah_takhtaei@yahoo.com
}

\begin{abstract}
Zahra Mousavi
Accounting Department, Andimeshk Branch, Islamic Azad University, Andimeshk, Iran
\end{abstract}

Received: April 22, 2012

doi:10.5296/ajfa.v4i2.1690
Accepted: May 30, 2012 Published: December 1, 2012

URL: http://dx.doi.org/10.5296/ajfa.v4i2.1690

\begin{abstract}
Our paper aims to examine the relationship disclosure quality and Firm characteristics for a sample of 80 firms listed in the Iran financial market during 2006-2009. We use a linear regression analysis to examine the association between the disclosure quality and firm's characteristics measured by variables such as Current ratio, Acid ratio, Firm Size and P/B ratio.The results of study show that the disclosure quality is having positive and significant relation with Current Acid and $\mathrm{P} / \mathrm{B}$ ratios. Also, we find that there is a significant and negative association between disclosure quality and Firm Size.
\end{abstract}

Keywords: Disclosure Quality, Transparency, Financial Reporting 


\section{Introduction}

Disclosure is a comprehensive term in accounting and includes all of the financial reporting process approximately. One of the primary principles of accounting is disclosure principle of all the material and relevant facts in regard to financial events and transactions of profit-seeking organization particularly public companies. Adequate, proper and complete terms are characteristics that are often used in order to describe the disclosure. In accounting and auditing texts, according to the perception of the every author with regard to disclosure, expressions of adequate disclosure, proper disclosure and complete disclosure, in terms of, have been referred to as well. However, the most common theories among these mentioned concepts, adequate disclosure is that as least indicate required disclosure and is consistent with this negative phrase (financial statements must not be misstatement). Adequate and proper characteristics are more positive concepts.

Proper disclosure is based on the ethics that all potential users be considered the same with regard to the financial information disclosure. Complete disclosure indicating the present of all information in a way that financial statement show complete picture concerning events and transactions of business enterprise. Although, it is necessary to be presented financial statement completely but, it is not included unimportant information. Because, users of financial statements may pay attention to less important information and as a result of this, neglect important events and operations (Alivar, 2006 ).

The purpose of disclosure in financial reporting, presenting the required information in order to achieve the following goals: 1) Performance valuation of business enterprise 2) Judgments on how existing resources are used by business enterprise and 3) Predict the trends of business enterprise's profitability in the future. Therefore, information is presented by use of financial reports must be reliable, relevance, proper and complete. The needs and requirements of main investors, investment companies, creditors and analytics should be considered. As a rule, Performance valuation of business enterprise, Judgments on how existing resources are used by business enterprise, and predict the trends of business enterprise's profitability in the future can take into account as the purpose of financial information disclosure.

The subject of information disclosure is not only limited to the exclusive users but also consists of people's necessity in the society such as professional institutions, creditors, government, investors and other decision-makers. Disclosure increase transparency while market transparency is observed as a fundamental mechanism in order to decrease the information asymmetry among the market's participants (Bleck and Liu 2007). Disclosure helps the stockholders and other participants in market to organize their operations favorably. The investors can buy and sell stocks accurately and have control over the company with the help of proper disclosure of information (Kanda 2001).

Increasing the information disclosure is useful for the users who are not able to determine future viewpoint of the company (Dastgir and BazazZadeh 2003). The high level of disclosure will make reliability of investors in companies increase and hence efficiency in capital market. 
Prior research indicates that it can be a significant relationship between some of the financial characteristics and firms' disclosure quality. (Naser and Al-Khatib 2000; Naser, Al-Khatib et al. 2002; Abd-Elsalam and Weetman 2003; Hassan, Giorgioni et al. 2006; Dahawy 2009; Hussainey and Mouselli 2010).

Using a sample of 80 Iranian firms on the period of 2005-2009, we first examine the relationship between disclosure quality and firm's characteristics. We use Current ratio, Acid ratio, Price-to-book ratio and Firm size for the firm characteristics. The results of our study show that there is a positive and significant relationship between disclosure quality and Current ratio, Acid ratio, Price-to-Book ratio, while there is a negative and significant relationship between disclosure quality and firm size. The reminder of the paper is structured as follows: section 2 reviews previous literature relevant to this paper. Section 3 establishes the hypotheses. Section 4 details research method and sample selection. Section 5 presents the results of the findings and analysis. Finally, section 6 provides the conclusion of the study.

\section{Literature Review}

Dohawy(2009) investigated the relationship between company characteristics and disclosure level. The study is based on the manual examination of the disclosure of the most activity traded 41 companies listed on the Cairo and Alexandria Stock Exchange (CASE), using a disclosure checklist issued by the Egyptian Capital Market Authority (CMA). A quantitative analysis is then used to test the relationship between corporate characteristics and disclosure level. The findings of research indicate that the degree of disclosure by Egyptian companies is affected by the highly secretive Egyptian culture. The results further indicate that the degree of affiliation of the auditor with an international firm is the most significant variable affecting the level of disclosure by Egyptian companies and are then compared to their counterparts in previous studies.

Hussainey and Mouselli(2010) studied the relationship between disclosure quality and stock returns in the UK. The purpose of the their study was to update and re-examine the role of corporate narrative reporting in improving investors' ability to better forecast future earnings change. They also construct a risk factor for disclosure quality and test whether such a factor is useful in explaining the time-series variation of UK stock returns. Their paper contributes to the market based accounting research in three crucial ways. Firstly, it offers updated evidence on the usefulness of corporate narrative reporting to investors. Secondly, in offers evidence that the disclosure quality factor is a significant risk factor in the UK and finally, it finds that Fama-French might contain disclosure quality related information.

Abd-Elsalam and Weetman(2003) measure the accounting disclosure in Egypt linking it with the inception of the required implementation of IAS in Egypt. Moreover, they investigated the correlation between some variables and level of disclosure. Their results show that IAS disclosure level was associated with audit firm type, business type, leverage, liquidity and legal form. 
Previous research provide evidence that there is no significant relationship between leverage and level of the disclosure (Cooke 1989; Ahmed and Nicholls 1994; Wallace, Naser et al. 1994; Meek, Roberts et al. 1995; Wallace and Naser 1996; Naser 1998; Camfferman and Cooke 2002; Archambault and Archambault 2003; Ali, Ahmed et al. 2004; Alsaeed 2006; Mangena and Tauringana 2007) However, Naser and Al-Khatib(2000)Naser and Al-Khatib and Naser, Al-Khatib et al. (2002) and Hassan, Giorgioni et al. (2006) reports findings that there is a significant relationship between leverage and disclosure level.

ArabMazarYazdi and Arzitoun(2005) investigated the financial disclosure on companies financial reporting. The purpose of the study was the examination of the relationship between companies' characteristics and disclosure.

As an actual, it is attempted to be assessed the aspects of information disclosure's quality and quantity in Iran meanwhile examining the annual reports. The trend of information disclosure was examined in the formats of three company's characteristics such as assets amount, profit margin, and industry nature. In the study, disclosure index has consisted of 55 items that take into consideration 109 items with the subsidiary items. These items cover the contents of an annual report absolutely. The items have been selected in accordance with the presented policies and then suitable adjustments.

The results indicates that 1) the relationship between company size (total assets) and company disclosure number is positive and significant statistically 2) the relationship between profit margin and company disclosure number is positive and significant statistically 3) the company size (total assets) has a better relationship with disclosure level other than profit margin 4) there is no significant relationship between company industry type and company disclosure number that it means nature of industry has no effects on disclosure level in reporting annually.

\section{Development of hypothesis}

Wallace, Naser et al. (1994) argued that firms with a low liquidity position might disclose more information to justify their liquidity status on the other hand, Belkaoui and Kahl(1978) found no relationship between liquidity and disclosure. Also, Belkaoui and Kahl(1978) and Cooke (1989) suggested that the soundness of the firm as portrayed by high liquidity is associated with greater levels of disclosure (Barako, Hancock et al. 2007). Therefore:

\section{H1: There is significant relationship between the Disclosure Quality and Current Ratio.}

H2:There is significant relationship between the Disclosure Quality and Acid Ratio.

Most studies indicated that is a positive relationship between disclosure quality and firm size (Naser and Al-Khatib 2000; Street and Bryant 2000; Alsaeed 2006; Mangena and Tauringana 2007). Based on the previous studies, the following hypothesis is developed: on other hand firms with weak liquidity ratios may wish to disclose more information to explain the reasons for such situation and to assure investors of its short - term nature. Thus liquidity may have effect on disclosure (Laidroo 2009):

H3: There is significant relationship between the Disclosure Quality and Firm Size. 
Akerlof(1970) stated that a well-run firm ( with higher profitability and higher growth rates would want to distinguish itself from a lemon . it means that if the company is performing well its superiority can be signaled (Ross Spring, 1977), information asymmetry between investors and managers reduced and agency costs reduced (Jensen and Meckling 1976) through increased disclosure (Laidroo 2009). Thus:

H4: There is significant relationship between the Disclosure Quality and Price-to-Book value.

\section{Methodology}

\subsection{Sample Selection}

The study sample comprises all non-financial listed companies traded on the Tehran Stock Exchange. During data collection, some companies that possess the following conditions or presented insufficient data to construct all variables have excluded:

1. Due to their having a nature of operation different from other corporates, investment and financial corporates have been omitted from sample of research.

2. The firms with fiscal year not ending to 20 march (year-end- in Iran), were excluded from sample of research.

3. Loss firms are excluded from our sample.

4. Required information such as financial statements and notes to financial statements, summary of decisions taken by regular general meeting having been published by stock exchange organization are available.

Finally, a total of 80 companies out of the total population are selected. The same procedure is applied for years 2005 till 2009 with a total of 320 companies out of the total population are chosen.

\subsection{Research method}

The correlation analysis is used in this study. Correlation researches are researches that researcher try to determine relationship between different variables using with correlation coefficient. In these researches, appointment coefficient is criterion that this criterion describes relationship between independent and dependent variables. Amount of this coefficient states what percentage of changes in dependent variable is described by independent variable. The linear regression method has been used extensively to link the disclosure quality and firm characteristics. Also, we used descriptive statistics such as central indexes as well as dispersion for data analyzing.

\subsection{Variables Definition}

\subsubsection{Dependent variable}

\section{- Disclosure quality}

Disclosure quality number allocated to the companies by use of Tehran stock exchange. In this study the annual scores is used to measure the disclosure quality of the listed firms in 
Tehran stock exchange. Disclosure quality scores in measured based on timeliness, reliability of disclosed information. To measure the scores of disclosure quality the weight of reliability is $1 / 3$ and the weight of timeliness is $2 / 3$.

\subsubsection{Independent variables}

- Current ratio: current assets divided by current liability.

- Acid ratio: (current assets minus inventory) divided by current liability.

- $\quad$ Firm size: total asset is used as a proxy for firm size.

- $\quad$ Price to book value (P/B): market value divided by book value stock.

\section{Data Analysis}

\subsection{Descriptive Analysis}

Table 1 provides the descriptive statistics for all variables utilized in this study. This table reports the mean, minimum, maximum, mean, variance and standard deviation.

This table presents the summary of descriptive statistics of variables. The results indicates that number of companies investigated in this study are 240, the minimum and maximum number allocated for the firms' disclosure quality are 2 and 100, the minimum and maximum current ratio are 0.24 and 3.79, the minimum and maximum acid ratio are 0.04 and 3.79, the minimum and maximum for firm size variable are 4.29 and 7.83 , the minimum and maximum for price-book value are 0 and 3.14 respectively.

With regard to disclosure quality, the mean is equal to 54.3220, which indicate the allocated number average of disclosure quality for firms listed in Tehran stock exchange is 54 .

Concerning current ratio, the mean is equal to 1.2488, which shows current assets are more than current liabilities and companies are able to pay the liabilities. The mean acid ratio is 0.7253, which in terms of this variable shows current assets are less than current liabilities and companies are not able to pay the liabilities. The mean firm size is 5.7829, that we state the average price-book value for firms per year are 5.7829. In regard to the last of variables studied, we observed that the average price-book value for firms per year is 0.6218 .

\subsection{Correlation Analysis}

Table 2 presents the correlation matrix of the variables, from which, it has observed that thecorrelation between disclosure quality and current ratio is 0/145. Also, Pearson correlation between disclosure quality and Acid ratio, Firm size and P/B ratio are 0/131, -0/138, and $0 / 212$.

Table 3 indicates the multiple regressions, $\mathrm{R}$ Square, Adjusted R Square and Standard deviation of the estimation. The R, R Square and Adjusted R Square are equal to 0.262, 0.069 and 0.052 respectively which it means that there is a poor correlation between disclosure quality as dependent variable and other investigated dependent variables in this study. Furthermore, indicate that 5 percent of changes (variance) of disclosure quality are 
determined by use of investigated independent variables in this study and 95 percent of change is conditional upon variables that have not been investigated in this study. In other words, the regression model is not able to fit the investigated data.

Table 4 shows the $\mathrm{R}$ Square significance test. $\mathrm{F}$ indicates if the regression model of our study is model proper or not. As F=4.255 and sig=0.002 and P-value is less than 0.05; consequently it shows that variables have high determination power and are able to describe the dependent variable variance. In other words, our study model regression is a suitable model and by use of the model is able to determine variation of the disclosure quality in accordance with the investigated independent variables.

Table 5 points out results with regard to regression effect coefficients of investigated independent variables in this study on disclosure quality as dependent variable.

\section{Conclusion}

The subject of information disclosure is not only limited to the exclusive users, but also consists of people's necessity in the society such as professional institutions, creditors, government, investors and other decision-makers. Disclosure increase transparency while market transparency is observed as a fundamental mechanism in order to decrease the information asymmetry among the market's participants. Disclosure helps the stockholders and other participants in market to organize their operations favorably. The investors can buy and sell stocks accurately and have control over the company with the help of proper disclosure of information. Increasing the information disclosure is useful for the users who are not able to determine future viewpoint of the company (Dastgir and BazazZadeh 2003). The high level of disclosure will make reliability of investors in companies increase and hence efficiency in capital market. The objective of this study was focused on the relationship between disclosure quality and some firm's financial characteristics in Tehran stock exchange. Our paper aims to examine the relationship disclosure quality and Firm characteristics for a sample of 80 firms listed in the Iran financial market during 2006-2009. We use a linear regression analysis to examine the association between the disclosure quality and Current ratio, Acid ratio, Firm size and $\mathrm{P} / \mathrm{B}$ ratio. The results of study show that the disclosure quality is having positive and significant relation with Current, Acid and P/B ratios. Also, we find that there is a significant and negative association between disclosure quality and Firm Size.

\section{References}

Ahmed, K., \& D. Nicholls. (1994). The impact of non-financial company characteristics on mandatory disclosure compliance in developing countries: The case of Bangladesh. The International Journal of Accounting, 29(1), 62-77. http://dx.doi.org/10.1111/j.1539-6975.2010.01399.x

Ali, M. J., K. Ahmed. (et al). (2004).Disclosure compliance with national accounting standards by listed companies in South Asia. Accounting and Business Research, 34(3), 183-199. http://dx.doi.org/10.1080/00014788.2004.9729963 
Alivar, A. (2006). Disclosure in financial reporting. Center for Professional Accounting \& Auditing Studies: Audit Organization.

Alsaeed, K. (2006). The association between firm-specific characteristics and disclosure: the case of Saudi Arabia. Managerial Auditing Journal, 21(5), 476-496. http://dx.doi.org/10.1108/02686900610667256

ArabMazarYazdi, M., \& R. Arzitoun. (2005). The relationship of financial structure characteristics and firms performance with information disclosure level in financial statements. Auditing Knowledge Quarterly, 22.

Archambault, J. J., \& M. E. Archambault. (2003). A multinational test of determinants of corporate disclosure. The International Journal of Accounting, 38(2), 173-194. http://dx.doi.org/10.1016/S0020-7063(03)00021-9

Barako, D. G., P. Hancock. (et al). (2007). Determinants of voluntary disclosures in Kenyan companies annual reports. African Journal of Business Management, 1(5), 113-128. http://dx.doi.org/10.1108/09675421011069513

Belkaoui, A., \& A. L. Kahl. (1978). Corporate financial disclosure in Canada. Canadian Certified General Accountants' Association.

Bleck, A., \& X. Liu. (2007). Market transparency and the accounting regime. Journal of Accounting Research, 45(2), 229-256. http://dx.doi.org/10.1111/j.1475-679X.2007.00231.x

Camfferman, K., \& T. E. Cooke. (2002). An analysis of disclosure in the annual reports of UK and Dutch companies. Journal of International Accounting Research, 1(1), 3-30. http://dx.doi.org/10.2308/jiar.2002.1.1.3

Cooke, T. E. (1989). Voluntary corporate disclosure by Swedish companies. Journal of International Financial Management \& Accounting, 1(2), 171-195. http://dx.doi.org/10.1111/j.1467-646X.1989.tb00009.x

Dahawy, K. (2009). Company characteristics and disclosure level: The case of Egypt. International Research Journal of Finance and Economics, 34, 194-208.

Dastgir, M., \& H. R. BazazZade.h (2003). The effect of the level of disclosue on cost of equity capital. Financial Research, 5(16), 83-103.

Hassan, O. A. G., G. Giorgioni. (et al). (2006). The extent of financial disclosure and its determinants in an emerging capital market: the case of Egypt. International Journal of Accounting, Auditing and Performance Evaluation, 3(1), 41-67.

Hussainey, K., \& S. Mouselli. (2010). Disclosure quality and stock returns in the UK. Journal of Applied Accounting Research, 11(2), 154-174. http://dx.doi.org/10.1108/09675421011069513

Jensen, M. C., \& W. H. Meckling. (1976). Theory of the firm: Managerial behavior, agency costs and ownership structure. Journal of Financial Economics, 3(4), 305-360. http://dx.doi.org/10.1002/9780470752135.ch17 
Kanda, H. (2001). Disclosure and corporate governance: a Japanese perspective. Corporate governance in Asia: a comparative perspective, 149.

Laidroo, L. (2009). Association between ownership structure and public announcements' disclosures. Corporate Governance: An International Review, 17(1), 13-34. http://dx.doi.org/10.1111/j.1467-8683.2008.00717.x

Mangena, M., \& V. Tauringana. (2007). Corporate compliance with non-mandatory statements of best practice: The case of the ASB statement on interim reports. European Accounting Review, 16(2), 399-427. http://dx.doi.org/10.1080/09638180701391014

Meek, G. K., C. B. Roberts. (et al). (1995). Factors influencing voluntary annual report disclosures by US, UK and continental European multinational corporations. Journal of International Business Studies, 26(3), 555-572. http://dx.doi.org/10.1057/palgrave.jibs.8490186

Naser, K. (1998). Comprehensiveness of disclosure of non-financial companies: Listed on the Amman financial market. International Journal of Commerce and Management, 8(1), 88-119. http://dx.doi.org/10.1108/eb047365

Naser, K., \& K. Al-Khatib. (2000). The Extent of voluntary disclosure in the board of directors' statement: The case of Jordan. Advances in International Accounting, 13, 99-118.

Naser, K., K. Al-Khatib. (et al). (2002). Empirical evidence on the depth of corporate information disclosure in developing countries: the case of Jordan. International Journal of Commerce and Management, 12(3/4), 122-155. http://dx.doi.org/10.1108/eb047456

Ross, S. A. (Spring, 1977). The Determination of Financial Structure: the incentive-signaling approach. The Bell Journal of Economics, 8(1), 23-40. http://dx.doi.org/10.2307/3003485

Street, D. L., \& S. M. Bryant (2000). Disclosure level and compliance with IASs: a comparison of companies with and without US listings and filings. The International Journal of Accounting, 35(3), 305-329. http://dx.doi.org/10.1016/S0020-7063(00)00060-1

Wallace, R., \& K. Naser. (1996). Firm-specific determinants of the comprehensiveness of mandatory disclosure in the corporate annual reports of firms listed on the stock exchange of Hong Kong. Journal of Accounting and Public Policy, 14(4), 311-368. http://dx.doi.org/10.1016/0278-4254(95)00042-9

Wallace, R. S. O., K. Naser. (et al). (1994). The relationship between the comprehensiveness of corporate annual reports and firm characteristics in Spain. Accounting and Business Research, 25(97), http://dx.doi.org/10.1080/00014788.1994.9729927

\section{Acknowledgment}

The research is financed by Islamic Azad University, Dezfoul Branch. 


\section{Appendices}

Table1. Descriptive statistics of variables

\begin{tabular}{lccccccc}
\hline Variables & $\mathrm{N}$ & Minimum & Maximum & \multicolumn{2}{c}{ Mean } & Std. Deviation & Variance \\
& & & & & & & \\
& Statistic & Statistic & Statistic & Statistic & Std. Error & Statistic & Statistic \\
\hline Disclosure & 240 & 2.00 & 100.00 & 54.3220 & 1.49544 & 22.97339 & 527.777 \\
current & 240 & .24 & 3.79 & 1.2488 & .03528 & .54656 & .299 \\
Acid & 240 & .04 & 3.79 & .7253 & .02997 & .46435 & .216 \\
Size & 240 & 4.29 & 7.83 & 5.7829 & .03740 & .57943 & .336 \\
P/B & 240 & .00 & 3.14 & .6218 & .03447 & .53402 & .285 \\
\hline
\end{tabular}

Table 2. Correlations MATRIX

\begin{tabular}{|c|c|c|c|c|c|c|}
\hline & & Disclosure & Current & Acid & Size & $\mathrm{P} / \mathrm{B}$ \\
\hline \multirow[t]{3}{*}{ Disclosure } & Pearson Correlation & 1 & $.145^{*}$ & $.131^{*}$ & $-.138^{*}$ & $.212^{* *}$ \\
\hline & Sig. (2-tailed) & & .026 & .044 & .035 & .001 \\
\hline & $\mathrm{N}$ & 236 & 236 & 236 & 236 & 236 \\
\hline \multirow[t]{3}{*}{ Current } & Pearson Correlation & $.145^{*}$ & 1 & $.861^{* *}$ & $-.251^{* *}$ & .107 \\
\hline & Sig. (2-tailed) & .026 & & .000 & .000 & .098 \\
\hline & $\mathrm{N}$ & 236 & 240 & 240 & 240 & 240 \\
\hline \multirow[t]{3}{*}{ Acid } & Pearson Correlation & $.131^{*}$ & $.861^{* *}$ & 1 & $-.150^{*}$ & .047 \\
\hline & Sig. (2-tailed) & .044 & .000 & & .020 & .471 \\
\hline & $\mathrm{N}$ & 236 & 240 & 240 & 240 & 240 \\
\hline \multirow[t]{3}{*}{ Size } & Pearson Correlation & $-.138^{*}$ & $-.251^{* *}$ & $-.150^{*}$ & 1 & -.122 \\
\hline & Sig. (2-tailed) & .035 & .000 & .020 & & .059 \\
\hline & $\mathrm{N}$ & 236 & 240 & 240 & 240 & 240 \\
\hline \multirow[t]{3}{*}{$\mathrm{P} / \mathrm{B}$} & Pearson Correlation & $.212^{* *}$ & .107 & .047 & -.122 & 1 \\
\hline & Sig. (2-tailed) & .001 & .098 & .471 & .059 & \\
\hline & $\mathrm{N}$ & 236 & 240 & 240 & 240 & 240 \\
\hline
\end{tabular}

Table 3. Model Summary

\begin{tabular}{ccccc}
\hline Model & $\mathrm{R}$ & R Square & Adjusted R Square & Std. Error of the Estimate \\
\hline 1 & $.262^{\mathrm{a}}$ & .069 & .052 & 22.36227 \\
\hline
\end{tabular}


Table 4. ANOVA (Analysis of Variance)

\begin{tabular}{|c|c|c|c|c|c|}
\hline Model & Sum of Squares & $\mathrm{df}$ & Mean Square & $\mathrm{F}$ & Sig. \\
\hline Regression & 8511.116 & 4 & 2127.779 & 4.255 & $.002^{\mathrm{a}}$ \\
\hline Residual & 115516.410 & 231 & 500.071 & & \\
\hline Total & 124027.525 & 235 & & & \\
\hline
\end{tabular}

a. Predictors: (Constant), PB, Acid, Size, current

b. Dependent Variable: Disclosure

Table 5. Coefficients ${ }^{\mathbf{a}}$

\begin{tabular}{rrccccc}
\hline \multicolumn{1}{l}{ Model } & \multicolumn{2}{c}{ Unstandardized Coefficients } & Standardized Coefficients & & \\
& & B & Std. Error & Beta & t & Sig. \\
\hline \multirow{4}{*}{ (Constant) } & 66.536 & 16.779 & & 3.966 & .000 \\
current & 1.271 & 5.395 & .030 & .235 & .814 \\
Acid & 3.915 & 6.205 & .079 & .631 & .529 \\
& Size & -3.759 & 2.621 & -.095 & -1.434 & .153 \\
1 & P/B & 8.398 & 2.812 & .192 & 2.986 & .003 \\
\hline
\end{tabular}

a. Dependent Variable: Disclosure

Table 6. Coefficients ${ }^{\mathbf{a}}$

\begin{tabular}{|c|c|c|c|c|c|c|}
\hline & \multirow[t]{2}{*}{ Model } & \multicolumn{2}{|c|}{ Unstandardized Coefficients } & \multicolumn{3}{|c|}{ Standardized Coefficients } \\
\hline & & $\mathrm{B}$ & Std. Error & Beta & $\mathrm{t}$ & Sig. \\
\hline & (Constant) & 48.709 & 2.240 & & 21.745 & .000 \\
\hline 1 & $\mathrm{P} / \mathrm{B}$ & 9.244 & 2.791 & .212 & 3.312 & .001 \\
\hline
\end{tabular}

a. Dependent Variable: Disclosure

Table 7. Excluded Variables ${ }^{\mathrm{b}}$

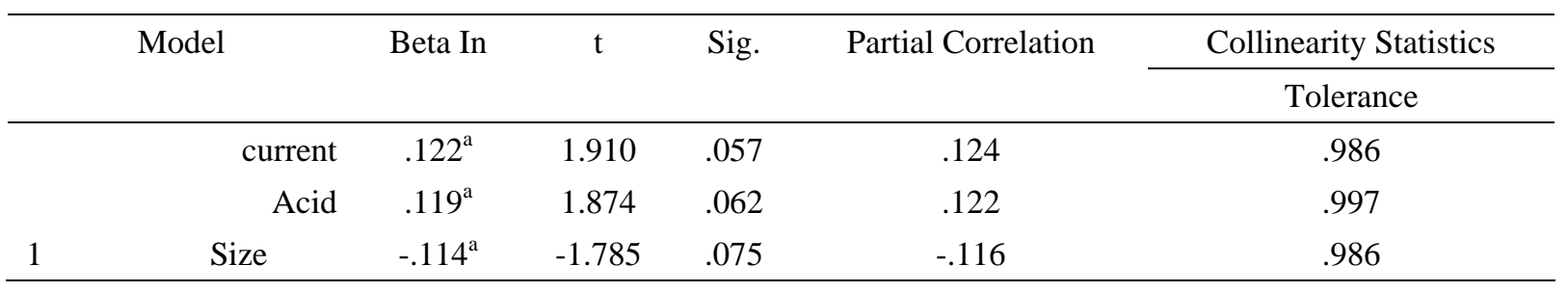

b. P/B 